US election

From frying-pan to Senate?

Washington

SiNCE the withdrawal earlier this year of Senator John Glenn from the competition for the Democratic presidential nomination, interest in the electoral fortunes of technically-minded members of the US Congress has centred on Representative Albert Gore's attempt to win the Senate seat being vacated by Senator Howard Baker, now the Republican leader in the Senate. Although Gore is a Democrat, his reputation in Washington, the strength of his roots in Tennessee and the swing of the political pendulum are reckoned to conspire to his advantage in November's general election.

During his eight years in Congress, Gore has principally made his mark as chairman of the investigations and oversight subcommittee of the House of Representatives Committee on Science and Technology. By using the subcommittee as a platform, from which he has launched inquiries into

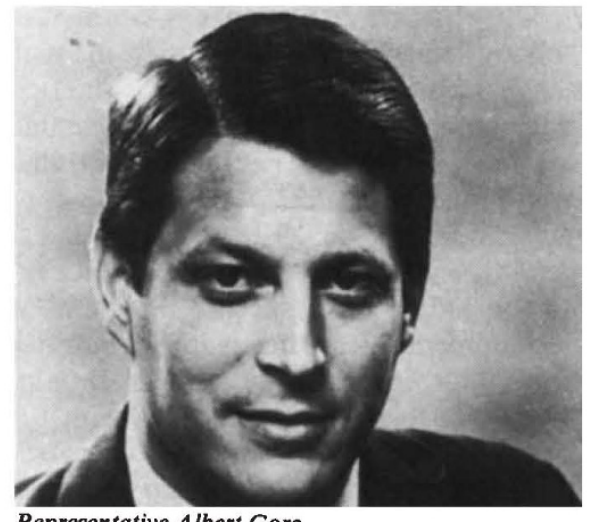

Representative Albert Gore

topics such as scientific fraud and the effects of automation on employment, Gore has provided yet another proof that virtually any power base will serve the needs of one who is sufficiently resourceful and energetic.

At 38 , Gore is as energetic as they come. His staff boasts of his voting record, saying that he has been on hand for 78 per cent of roll-calls in the House of Representatives during the past eight years. Philosophically, his line on science and technology is a blend of optimism and anxiety, that of an upbeat Alvin Toffler.

Just now, Gore is especially exercised by the question whether the coming of the fifth generation of computers (and "then the sixth generation") will cause intolerable social strains. While accepting that increased productivity may create extra jobs for those displaced from manufacturing, he is concerned that there may be insufficient opportunity for retraining and wonders "whether we will be imaginative enough to devise ways of compensating adequately" those destined to take jobs now badly paid.

\title{
Laboratory animals
} Berkeley fined for violations

\section{Washington}

THE University of California at Berkeley has been fined $\$ 12,000$ and ordered to correct long-standing deficiencies in its treatment of laboratory animals, the US Department of Agriculture (USDA) said last week.

Under the "consent decision" reached with the university, there was no admission of wrongdoing, but the university agreed to pay the fine - believed to be the largest ever assessed against a university in such a case - and take several specific steps to assure compliance with the requirements of the federal Animal Welfare Act. The university will have to run a training programme for those involved in animal care and will be required to establish an animal care committee that will oversee Berkeley's efforts to comply with the federal standards. At least one member of the committee must be a member of the community, not affiliated with the university, and involved neither in research nor the animal welfare movement. The committee must make quarterly reports to the chancellor of the university and to USDA for at least three years.
The university also moved last year to allocate half a million dollars for major renovations in its existing laboratory facilities. Two additional campus veterinarians were hired, a training programme was established and - apparently for the first time - the chief veterinarian was assured access to all animal facilities on campus.

The USDA fine was the culmination of years of efforts to get the university to correct apparent violations of the Animal Welfare Act. USDA inspection reports cite uncleaned cages, overheated and poorly ventilated rooms, overcrowding of animals, and feeders contaminated with urine and faeces. Numerous inspection reports note inadequate veterinary care or a lack of trained employees.

An attorney for USDA said the problems at Berkeley were primarily the result of careless attitudes and a failure of organization. He said there was no one with undisputed authority to order repairs or to have poor practices corrected.

Berkeley will be permitted to apply $\$ 10,000$ of the $\$ 12,000$ fine to its training programme.

\section{Koshland for Science post}

\section{Washington}

THE new Editor of Science magazine will be Dr Daniel E. Koshland Jr, professor of biochemistry at the University of California, Berkeley. Professor Koshland's appointment was announced last week by David Hamburg, president of the American Association for the Advancement of Science, and will take effect from 1 January 1985.

Koshland replaces Dr Philip Abelson, who has served as Editor of Science for the past 22 years. He will divide his time equally between the editorship and his university teaching and research in California, while a deputy editor (who is yet to be appointed) will look after much of the dayto-day running of the journal.

Koshland received his BSc at Berkeley in 1941 and his PhD from the University of Chicago in 1949. His research areas have been the regulation and control of enzyme activity, and more recently information processing in sensory cells. At present he is using recombinant DNA techniques to analyse components of chemotaxis in bacterial model system.

He is, he says, inheriting an "outstanding" journal from Dr Abelson, but denies that he will be a caretaker editor. He expects to be making some changes to Science to reflect the changing times and his own interests and says it will be a challenge to continue the progress established by his predecessor. While declining to be drawn on specifics, he does not rule out moves to increase the target group of the publication.

Koshland will relinquish his other editorial positions to devote all his time outside university to Science and will also be reducing his university teaching load, although the details of how he will divide his time between two jobs two and a half

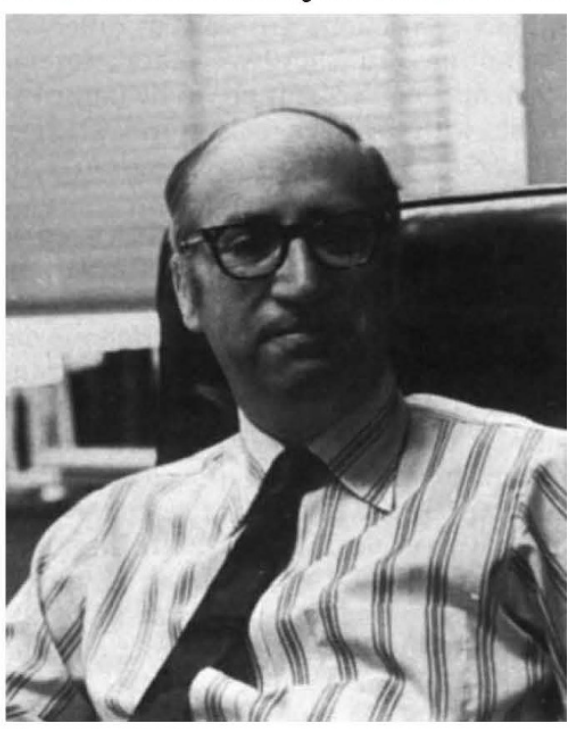

Daniel Koshland

thousand miles apart have yet to be settled. He expects to be active in soliciting leading articles and evaluating research reports. Does he see Nature as a major competitor? Possibly. But, he says, "there's room for both of us". Tim Beardsley 